\title{
Marolo (Annona crassiflora Mart.): a study of value chain and processing Síntia Carla CORREA ${ }^{1}$, Marcelo Lacerda REZENDE²*, Eric Batista FERREIRA², Luciana AZEVEDO ${ }^{1}$
}

\begin{abstract}
This article aims to discuss the needs and problems of marolo value chain, as well as to evaluate the rehydration process of this fruit as a possibility of using it as a by-product during the interharvest growth periods. The study of the value chain included interviews with producers, handlers, and fruit and by-product sellers. In order to evaluate the rehydration process of this fruit, marolo was dehydrated using a conventional procedure and freeze-drying. The experiments were conducted in a completely randomized design and a triple factorial scheme $(2 \times 2 \times 6)$. ANOVA was performed, followed by the Tukey's test $(p<0.05)$. Regression models were generated and adjusted for the time factor. The precariousness of the value chain of marolo was observed. The best procedure for marolo dehydration should be determined according to the intended use of the dehydrated product since the water-absorption capacity of the flour is higher and convective hot-air-drying is more effective in retaining soluble solids and reducing damage to the fruit. These results aim at contributing to the marolo value chain and to the preservation of native trees in the Brazilian savanna biome and can be used to analyze other underutilized crops.
\end{abstract}

Keywords: Annona crassiflora; value chain; rehydration.

\section{Introduction}

The world is presently over dependent on a few plant species, and the diversification of production and consumption habits include a broader range of plant species, in particular those currently identified as 'underutilized', which can contribute significantly to improve health and nutrition, livelihoods, household food security and ecological sustainability. They are also closely tied to cultural traditions, and therefore have an important role in supporting social diversity (JAENICK; HOSCHLE-ZELEDON, 2006). Among those plant species, Marolo (Annona crassiflora Mart.), also known as Araticum, a fruit found in the Brazilian savanna, has a wide variety of potential use in spite of being limited to the consumption in natura by local population or mainly used in the preparation of juices, ice-creams, jellies, and jams (DRAGANO et al., 2010; ROESLER et al., 2007).

Nevertheless, marolo trees are grown by subsistence farmers under small-holder farming conditions, providing a small but important income to their growers (ALMEIDA et al., 1998). Thus, marolo as well as other "underutilized" plants, despite offering enormous potential, lacks incentive to stimulate its plantation, commercialization, and research, which are factors that limit its utilization. In addition, since marolo is a seasonal fruit, its preservation by the drying process was seen as a possibility to fulfill the identified needs during the study of marolo value chain. This process may increase the shelf life of marolo, reducing post-harvest losses and producing a minor dependence on seasonal conditions, thus adding commercial value to the fruit (CORRÊA et al., 2011; DRAGANO et al., 2010). Although freeze-drying and convective hot-air-drying are processes widely used for preserving food material and most dry products must be rehydrated by immersion in water before use, rehydration of this fruit is a complex process. The rehydration characteristics are used as parameters to determine food quality by measuring the induced damage during drying and its reconstitution of properties (LEWICK, 1998; McMINN; MAGEE, 1997).

Accordingly, this article aims to discuss the needs and problems of marolo value chain, as well as to evaluate the rehydration process of this fruit as a possibility of using it as a by-product during the interharvest growth periods, especially by small producers.

The knowledge of particularities and needs of this production chain, focusing on the agriculture/food interface, allows upcoming technologies, strategies, and interventions to be available as alternatives for other underutilized crops. These alternatives, according to Kitinoja et al. (2011), can lead to many directions likely to have an impact on relieving poverty in developing countries.

\section{Materials and methods}

\subsection{Value chain of marolo}

Value chains comprise all activities required to enable farm products reach consumers, including agricultural production, processing, storage, marketing, distribution, and consumption (GÓMEZ et al., 2011).

The approach adopted in this study followed a method proposed by both Miles (2002) and Holtzman (2002) found in the World Bank "Guide to developing agricultural markets and agro-enterprises" and involved communities located in the

\footnotetext{
Received 13/7/2012

Accepted 27/3/2013 (005785)

${ }^{1}$ Nutrition Faculty, Alfenas Federal University - UNIFAL, CEP 37130-000, Alfenas, MG, Brazil

2 Institute of Exact Sciences, Alfenas Federal University - UNIFAL, Rua Gabriel Monteiro da Silva, 700, CEP 37130-000, Alfenas, MG, Brazil,

e-mail: marcelo.rezende@unifal-mg.edu.br

${ }^{*}$ Corresponding author
}

DOI: http://dx.doi.org/10.1590/S0101-20612013005000044 
savanna eco-region in the south of Minas Gerais state, Brazil (Figure 1).

Data collection was based on semi-structured questionnaires administered to different value chain positions (1) rural producers, (2) salespeople, and (3) manufacturers of marolo by products. The interviewees were asked to answer the corresponding questionnaires.

After the questionnaires were evaluated, the rehydration capacity of marolo products dehydrated by freeze-drying and convective hot-air-drying was studied with the aim of increasing the industrial use of marolo.

\subsection{Dehydration processes and yield}

Mature marolo fruits were harvested from a farm in the savanna eco-region located in the municipality of Machado in the state of Minas Gerais, Brazil. The fruits were randomized to provide 10-fruit experimental units per treatment. The carpels of mature fruits were processed by separating the pulp from the rind and the seeds.

Fresh marolo was dehydrated by the freeze-drying and convective hot-air-drying methods. Carpel and pulp dehydration by freeze-drying resulted in freeze-dried marolo carpels (FMC) and freeze-dried marolo flour (FMF). Carpel and pulp dehydration by convective hot-air-drying resulted in convective hot-air-dried marolo carpels (CMC) and convective hot-air-dried marolo flour (CMF). To obtain these products, the procedures according to Corrêa et al. (2011) were used, and a LIOTOP-L101 dryer (Brazil, São Carlos, Liobras) was used for the freeze-drying (F) method. The temperature and pressure in the closed drying chamber were $-51^{\circ} \mathrm{C}$ and $250 \mathrm{~Pa}$, respectively. Convective hot-air-drying (C) was conducted with a $400 \mathrm{ND}$ drier with air circulation (Brazil, Vargem Grande Paulista, Nova Ética). The air temperature was held at $50{ }^{\circ} \mathrm{C}$ for $20 \mathrm{~h}$, followed by $70{ }^{\circ} \mathrm{C}$ for $11 \mathrm{~h}$. The air flow rate was $2.0 \pm 0.1 \mathrm{~m} / \mathrm{s}$. Fresh marolo had 77.21 $\pm 0.42 \mathrm{~g} / 100 \mathrm{~g}$ moisture, and when the moisture dropped below $10 \mathrm{~g} / 100 \mathrm{~g}$, the samples were weighed. To calculate the yield of the dehydrated products, the difference between the initial and the final mass weight of samples was considered, which was then divided by their initial mass weight and multiplied by 100 .

\subsection{Rehydration experiments and kinetics}

The method reported by Lewick (1998) was used with some modifications. Freeze-dried and convective hot-air-dried products were rehydrated by immersion in water bath at room temperature $\left(25 \pm 1{ }^{\circ} \mathrm{C}\right)$. The samples were taken from the bath after $15,30,60,140,180$, and $260 \mathrm{~min}$ and weighed after draining the excess water with a paper filter. Each rehydration experiment was performed in triplicate. The dry matter of the rehydrated samples was determined gravimetrically using the oven-drying method at $105 \pm 3{ }^{\circ} \mathrm{C}$ for $24 \mathrm{~h}$.

The water-absorption capacity (WAC), dry-matter-holding capacity (DHC) and rehydration ability (RA) were calculated according to the following Equations (1 to 3):

$W A C=\frac{M r h(100-S r h)-M d(100-S d)}{M o(100-S o)-M d(100-S d)}$
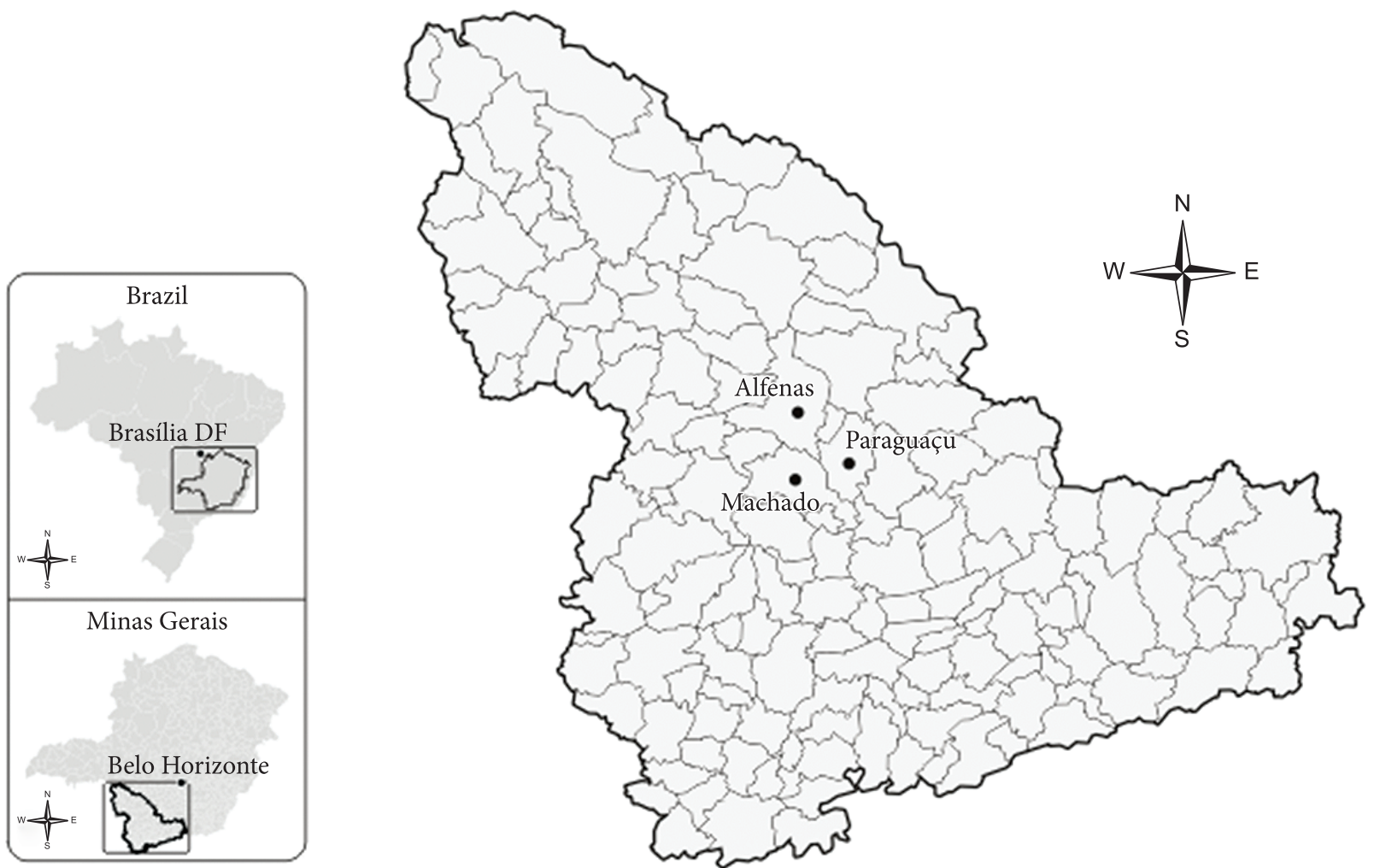

Figure 1. Geographical map of the region south of Minas Gerais and political division of the municipalities involved in the present study. 


$$
D H C=\frac{M r h \cdot S r h}{M d \cdot S d}
$$

$R A=W A C \cdot D H C$

where $M$ is the mass $(\mathrm{kg}), S$ is the dry matter (d.m.) content ( $\mathrm{kg} \mathrm{d}$.m. $\mathrm{kg}^{-1}$ ), and the subscripts $o, d$ and $r h$ refer to fresh, dehydrated, and rehydrated samples, respectively. The indexes WAC and DHC vary in the range from 0 to 1.

\subsection{Statistical analysis}

All reported values represent the average of at least three replicates. The experiment was conducted under a completely randomized design and triple factorial scheme $(2 \times 2 \times 6)$ : two fruit parts (carpel and pulp), two dehydration techniques (freeze-drying and convective hot-air-drying), and six times (15, $30,60,140,180$, and $160 \mathrm{~min})$. ANOVA was performed followed by the Tukey's test at $5 \%$ of significance, and regression models were fitted to the time factor. Polynomial regression models were considered as (Equation 4):

$\mathrm{Y}_{\mathrm{ij}}=\beta_{0}+\beta_{1} \mathrm{X}_{\mathrm{i}}+\beta_{2} \mathrm{X}_{\mathrm{i}}^{2}+\ldots+\beta_{\mathrm{k}} \mathrm{X}_{\mathrm{i}}^{\mathrm{k}}+\mathrm{e}_{\mathrm{ij}}$

where $Y_{i j}$ is the observed value on the $j$-th replication of the $i$-th treatment; $\beta$ are the regression parameters; $X_{i}$ is the $i$-th treatment level; and $e_{i j}$ is the random error associated with $Y_{i j}$, which is assumed to follow a Gaussian distribution with a null mean and common variance. All fitted models presented significant coefficients $(\mathrm{p}<0.05)$ by the Student's t-tests.

Before the use of ANOVA, the homogeneity of variances within the treatments was confirmed by Bartlett's test (at $5 \%$ of significance).

\section{Results and discussion}

Due to population pressure, increasing urbanization, and the growth of monoculture settlements, such as coffee (BRANNSTROM et al., 2008), there has been a significant decrease in the population of marolo plants in the region studied over the last few years, despite the confirmed economic, nutritional, and cultural value of this fruit.

Furthermore, the present study has proved that commercial plantations are rare, prevailing the extractivism. As a consequence, despite itsincreased consumption, this fruit has been scarcely explored commercially benefiting a small number of families.

In spite of these limitations, it was possible to interview 70 people involved in the production chain. From these 70 interviewees, $68.5 \%$ belong to a single sector of the production chain, which includes retailers of in natura marolo and its byproducts (50\%), product handlers who do not sell to consumers (39.5\%), and fruit producers (10.5\%). The remaining $32.5 \%$ work in two or three of these sectors; a total of 94 questionnaires were answered.

Figure 2 shows the value chain of marolo and its byproducts.
Although this structure has all of the elements of a value chain, there is a poor communication between the different players, without a formal interaction between them. According to Jaenick and Hoschle-Zeledon (2006), this lack of coordination is a frequent problem for activities with underutilized plants.

Questionnaire 1 was administered to rural producers, who correspond to $10 \%$ of the interviewed population. Among these producers, $60 \%$ are extractivists, $30 \%$ claim owning only commercial plantations, and the remaining $10 \%$ obtain the fruit both ways. One of the claims made by the producers is the invasion of their properties for the collection of marolo, leading to the cutting of native marolo trees in order to avoid damage to their properties.

The results of Questionnaire 2, which was administered to sellers, show that the commercialization of the fruit occurs mainly on the side of the road and street markets (80.5\%) and grocery stores $(19.5 \%)$, suggesting that the marolo trade is an informal economic activity.

Nevertheless, in $13 \%$ of the cases, the sale of marolo is the main source of income for families despite its seasonalities. Among the traders, $34 \%$ do not declare the origin of the fruit they sell. This fact confirms the information obtained from Questionnaire 1 in relation to property invasion.

In Brazil, such conflicts are also true for the pequi fruit (Caryocar brasiliense) as well as for the babaçu palm tree (Orbignya speciosa). As a solution, public authorities intervened to establish the "pro-pequi" and "free-babaçu" laws, making it forbidden to cut these trees. Some states and municipalities have also approved laws to guarantee the full maturation of pequi by prohibiting its collection directly from the tree. As for babaçu, these laws have granted babaçu-nut extractivist women free access to the native babaçu trees, which exist mainly in farmers' private properties (AFONSO, 2008). The same occurs in Alagoas and Sergipe states with the aroeira tree, where the properties do not belong to the extractivists, to whom this activity is an important source of income. This fact sparked socio-environmental conflicts (JESUS, 2010).

The high percentage of extractivism (60\%) surrounding the culture of marolo and the conflicts highlighted by the interviewees demonstrate the precariousness of this segment in the production chain, which is based on informal commercialization preventing the fruit and its by-products from reaching the population. Thus, this study reveals the need for further investigation on the effect of extractivism on this ecosystem, a fundamental aspect in the formulation of policies or even informal agreements to establish rules and control behaviors to ensure the sustainability of the savanna biome.

From the group of 32 handlers who answered the questionnaire, 3. $47 \%$ claim that the raw material was obtained from their own marolo production, $43 \%$ obtained the fruit from others, and $10 \%$ obtained it from both sources. The handlers who needed to obtain the fruit from third parties claimed that their main difficulties were related to the transportation of the fruit in natura, the high cost of marolo, and its scarcity in the market. 


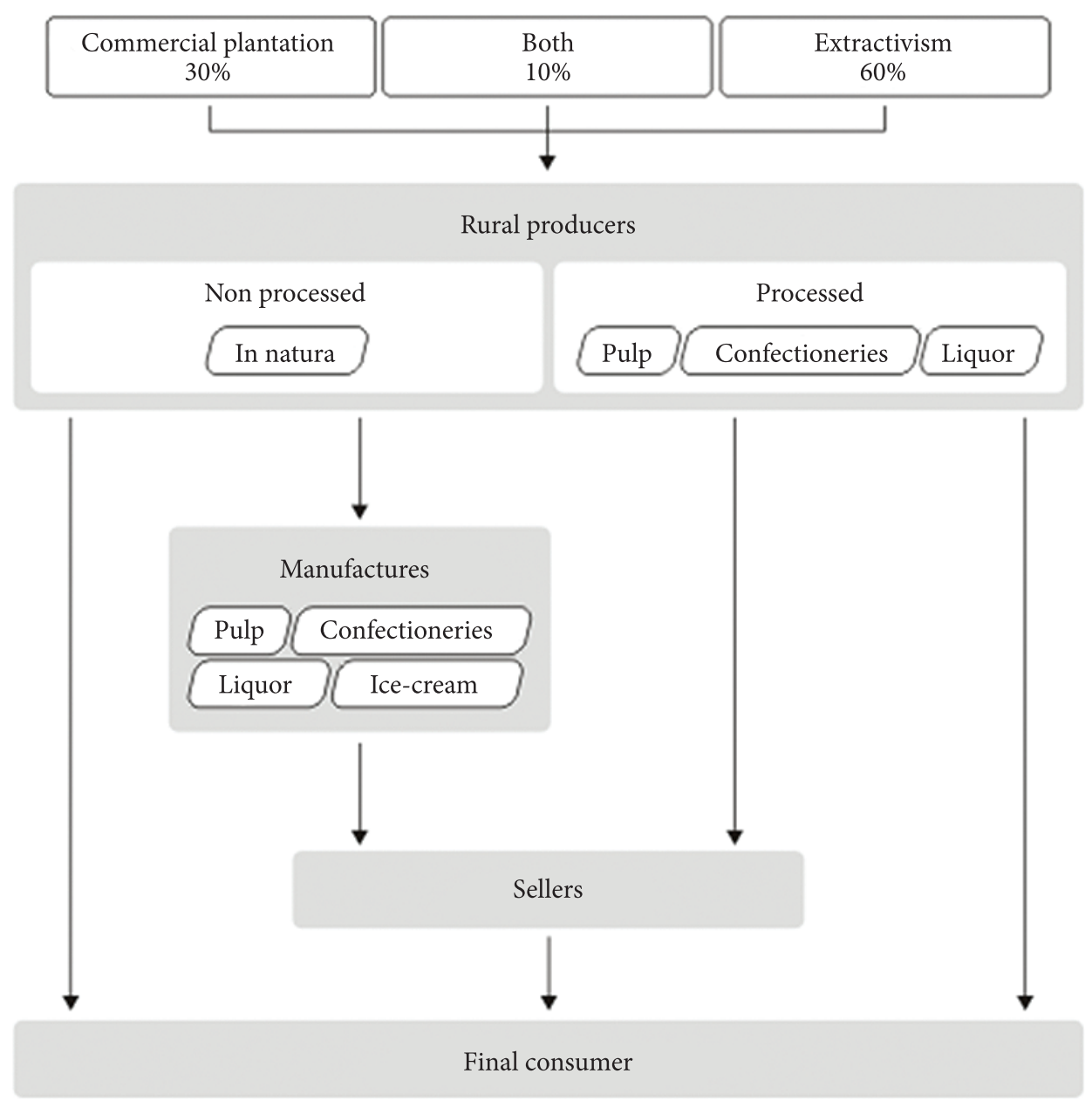

Figure 2. Value chain of marolo south of Minas Gerais State, Brazil.

The most commonly processed and commercialized products are confectioneries, ice cream, and liquor. However, the handlers did not show consistent criteria or standardization procedures when deciding what to produce. Therefore, there is no planning for production, which changes according to the availability and quality of the raw materials, labor, financial resources, structure of the working site and customer requests. Consequently, the commercialization of these products occurs in the town of origin in $67 \%$ of the cases.

Despite these limitations and production seasonality, 19\% of the handlers have this activity as the main source of income to support their families. Therefore, in addition to searching for an appropriate coordination structure, it is necessary to find technical and economic efficiency standards for the production of marolo and its by-products. This efficiency not only will allow the increase of many families' incomes, but it will also guarantee the sustainable development of the communities involved in such activity protecting the savanna and its natural resources. For this purpose, the follow-up of fruit production and consumers' requests and demands should be systematic. It is fundamental that the entire production chain organizes itself, especially in relation to post-harvest activities to improve the quality, identity, and competitiveness of marolo and its byproducts.
Regarding the need to increase the range of products, especially those that are "underutilized", the rehydration properties of marolo flour and carpels by freeze-drying and convective hot-air-drying were evaluated. With regards to the yield, the results obtained show that these dehydrated products did not differ ( $\mathrm{p}>0.05$ ) from each other: $27.62 \mathrm{~g} 100^{-1}$

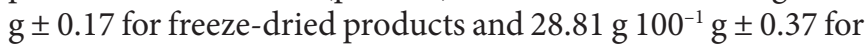
convective hot-air-dried products.

For the evaluation of proper rehydration, these four products were analyzed by WAC, DHC, and RA indexes, which take into account not only the water uptake but also the loss of soluble solids. These simultaneous processes depend on structural changes in the vegetable tissues and the cells of food material during dehydration, which cause shrinkage and collapse, as well as reduce the water-absorption capacity affecting the quality of the final product (KROKIDA; MARINOS-KOURIS, 2003; KROKIDA et al., 2003). As a result, these indexes applied to the four products were statistically different for each rehydration time indicating that the convective hot-air dried marolo was statistically different from the freeze-dried marolo at the rehydration times studied. For the WAC index, the significant differences in the rehydration as a function of time were determined mainly by the structure and characteristics of the dried samples, such as flour and pieces. They are represented 
by two curves in Figure 3a, where each curve was fitted to the mean values between freeze-dried and hot-air-dried samples.

Comparing the two products, Table 1 shows that the marolo flour (freeze-dried or convective hot-air dried) had higher water absorption rate in the beginning the process, at 15 minutes of rehydration (WAC 0.73 ), reaching an equilibrium in the water absorption at 60 minutes (WAC 0.79), when it began to lose mass. According to Moreira et al. (2008), this asymptotic behavior is related to the decrease in driving force of water transfer as rehydration progresses and the system is close to equilibrium.

On the other hand, Table 1 shows that the marolo carpels had lower WAC index, 0.54 and 0.62 for freeze dried at 15 and 60 minutes, respectively and even lower values for convective hot-air dried, 0.16 and 0.28 , at the same time lapses. Probably, this occurs due to the higher porosity of freeze dried products than that of convective hot-air dried ones, which involved water permeability by capillarity and diffusion, respectively (MARABI et al., 2003). This rehydration behavior indicates that the structure of the tissues and the characteristics of dried matter (e.g. WAC flour>carpels) were more important than those related to the drying process, probably due to the shrinking and closing in the carpels that avoid the passage of water (MOREIRA et al., 2008).

Figure $3 \mathrm{~b}$ showed the DHC index for the carpels and flour of the convective hot-air dried samples as well as the curve for freeze-dried marolo carpels. The freeze-dried flour showed no differences in DHC in the times investigated ( $p>0.05)$. Therefore, we highlight that carpels and flour hot-air-dried samples had better ability of retaining soluble solids during rehydration. This is an important fact since low DHC indexes reveal an elevated leaching of solutes, which may indicate losses in vitamins, sugars, and minerals (MARQUES; PRADO; FREIRE, 2009).

In addition, the results obtained show that the DHC (and as consequence, RA index) decreased while WAC index increased with time during rehydration, probably due to the loss of solids while the water was imbibed.

Due to these factors, we suggest rehydration for 15 minutes for the marolo flour, which had better WAC index than carpels since during this time it will have already reached an adequate rehydration and after this time the losses increase. Furthermore, the best procedure for marolo dehydration should be determined according to the intended use of the dehydrated product. The water-absorption capacity of the flour is higher and convective hot-air-drying is more effective in retaining soluble solids and reducing damage to the fruit.

Despite the fact that a comparison between indexes is difficult due to the differences in the experimental conditions used by different authors, the WAC index of flour (by freeze-dried and convective hot-air-drying) and freeze-dried carpels were even larger than those of freeze-dried pineapple, acerola, guava, mango, and papaya dehydrated by freeze-dried (MARQUES; PRADO; FREIRE, 2009). Conversely, the losses using DHC index are higher for these products than for chestnuts in all times using convective air-drying (MOREIRA et al., 2008).

The marolo products obtained and evaluated in this study may enable an adequate rehydration, followed by a improved handling of dried marolo and the development of alternative by-products such as ice cream, candy, jelly, and liquor.
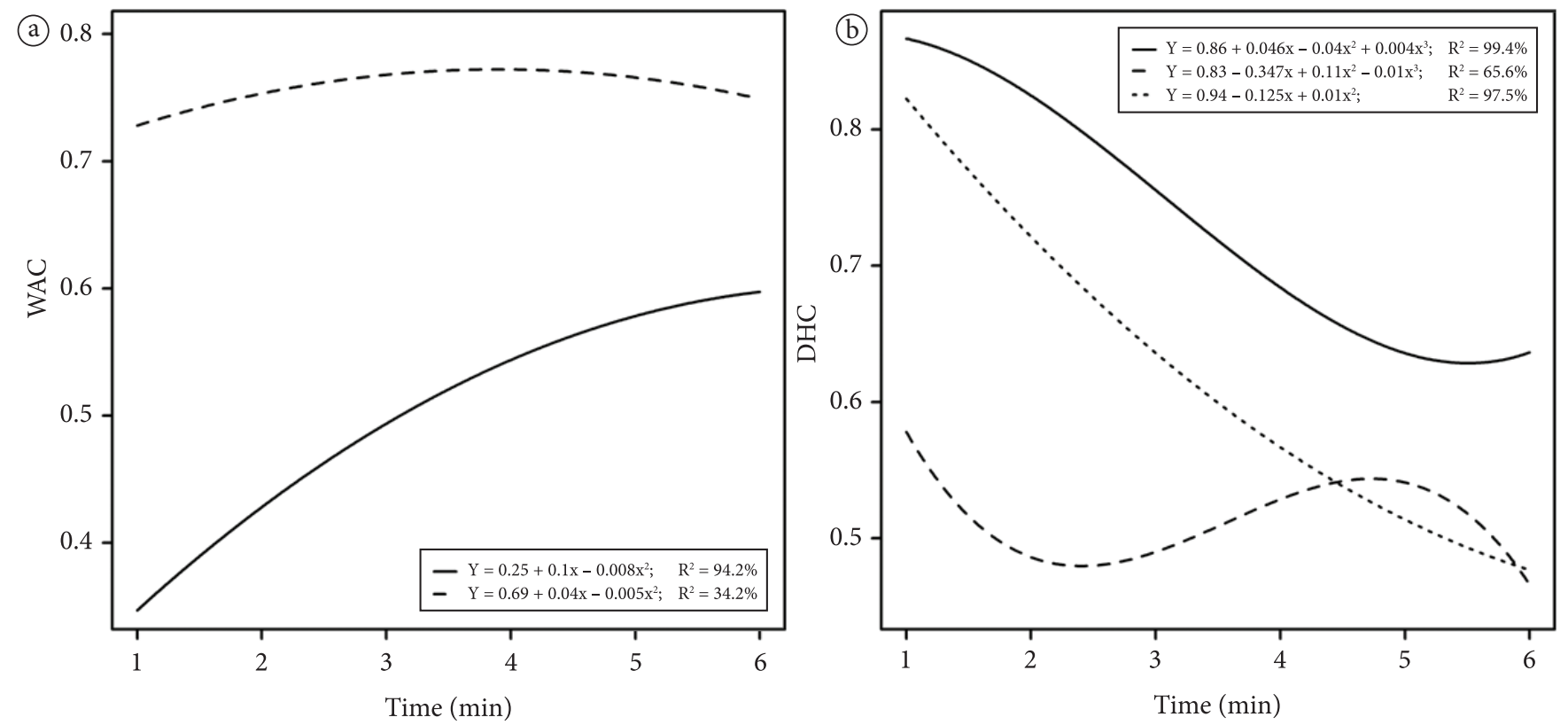

Figure 3. Fitted models (in function of time) for WAC index (a) of flours (hashed line) and dehydrated carpels (full line) of marolo and; for DHC index (b) from CMC (full line), CFM (dotted line) and FMC (hashed line). 
Table 1. Rehydration indexes of Freeze-dried marolo carpels (FMC); Freeze-dried marolo flour (FMF); Convective hot-air dried marolo carpels (CMC); and Convective hot air dried marolo flour (CMF).

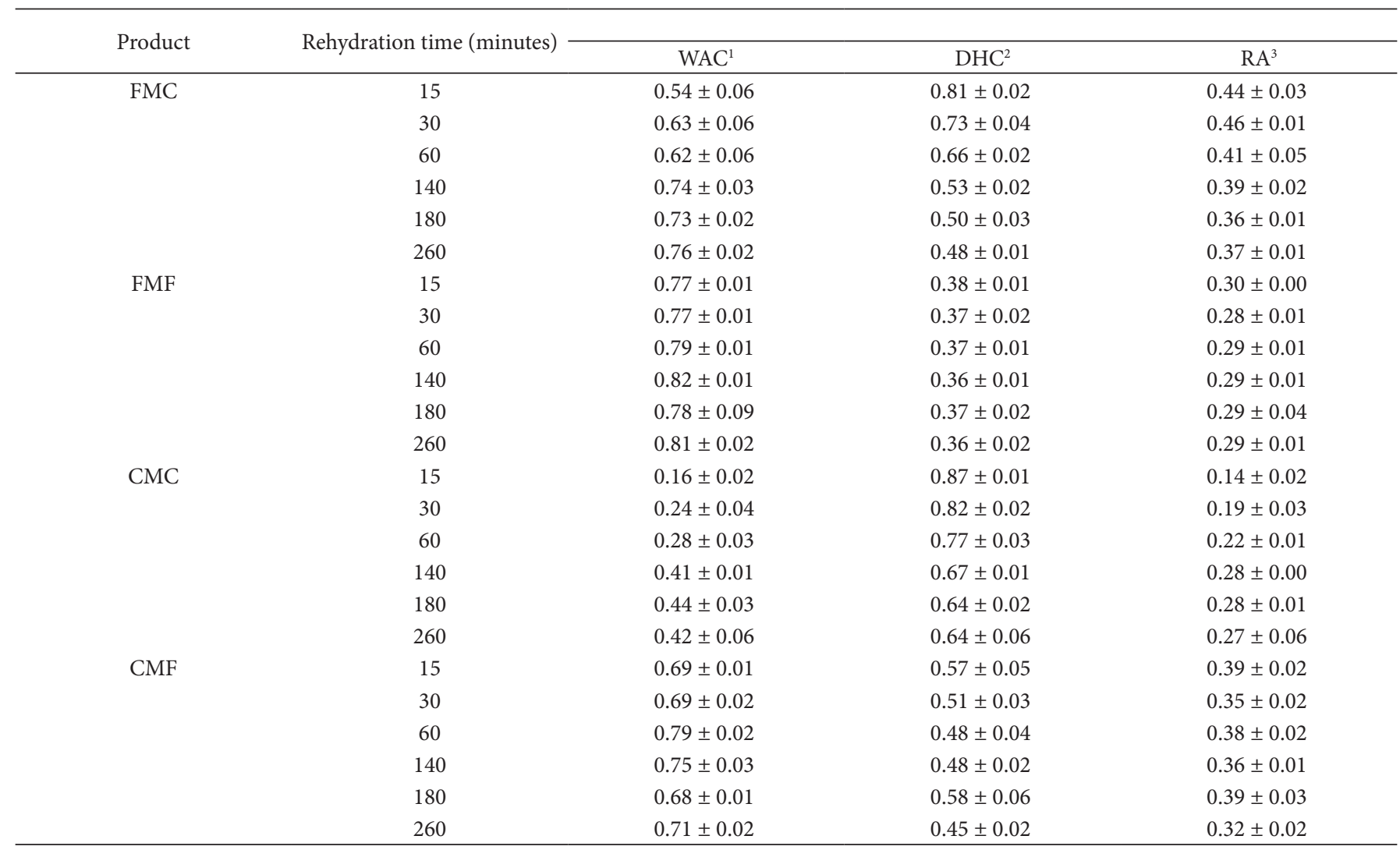

${ }^{1}$ Water-absorption capacity; ${ }^{2}$ Dry-matter-holding capacity; ${ }^{3}$ Rehydration ability.

\section{Conclusions}

The results obtained in the present study demonstrate the precariousness of the production and commercialization system of marolo regarding the predominance of extractivism, informal fruit sales, and the crafted processing of its by-products. On the other hand, the results also reveal the potential of this fruit to complement producers' incomes, indicating the fruit's ability to support value chain agents. Moreover, understanding the rehydration process of products dehydrated under different methods allows for the diversification of the use of marolo during interharvest growth seasons. These actions are aimed at promoting and enabling the preservation of native trees in the Brazilian savanna biome, and can be used in the study of other underutilized crops.

\section{Acknowledgements}

The authors are grateful for the financial support provided by the Brazilian funding agency FAPEMIG and for the scientific initiation scholarship granted to Síntia Carla Corrêa.

\section{References}

AFONSO, S. R. Análise sócio-econômica da produção de nãomadeireiros no cerrado brasileiro e o caso da cooperativa de pequi em Japonvar-MG. 2008. 107 f. Dissertação (Mestrado em Ciências Florestais)-Universidade de Brasília, Brasília, 2008.
ALMEIDA, S. P. et al. Cerrado: espécies vegetais úteis. Planaltina: Embrapa-CPAC, 1998.

BRANNSTROM, C. et al. Land change in the Brazilian Savanna (Cerrado), 1986-2002: comparative analysis and implications for land-use policy. Land Use Policy, v. 25, p. 579-595, 2008. http:// dx.doi.org/10.1016/j.landusepol.2007.11.008

CORRÊA, S. C. et al. Evaluation of dehydrated marolo (Annona crassiflora) flour and carpels by freeze-drying and convective hotair drying. Food Research International, v. 44, p. 2385-2390, 2011. http://dx.doi.org/10.1016/j.foodres.2011.02.052

DRAGANO, N. R. V. et al. Influence of marolo (Annona crassiflora Mart.) pulp intake on the modulation of mutagenic/antimutagenic processes and its action on oxidative stress in vivo. Plant Foods for Human Nutrition, v. 65, p. 319-325, 2010. PMid:20878359. http:// dx.doi.org/10.1007/s11130-010-0191-3

GÓMEZ, M. I. et al. Research principles for developing country food value chains. Science, v. 332, p. 1154-1155, 2011. PMid:21636760. http://dx.doi.org/10.1126/science.1202543

HOLTZMAN, J. S. Rapid appraisals of commodity subsectors. In: GIOVANNUCCI, D. (Ed.). A guide to developing agricultural markets and agro-enterprises. World Bank: Washington, 2002. Disponível em: <http://go.worldbank.org/J01X2X95U1> Acesso em: 10 nov. 2010.

JAENICK, H.; HOSCHLE-ZELEDON, I. Strategic framework for underutilized plant species research and development, with special reference to Asia and Pacific, and to Sub-Saharan Africa. Rome: International Centre for Underutilized Crops, 2006. 
JESUS, N. B. Relações socioambientais no extrativismo da aroeira (Schinus terebenthifolius Raddi) no baixo São Francisco SE/ AL. 2010. Dissertação (Mestrado em Desenvolvimento e Ciências Ambientais)-Universidade Federal de Sergipe, São Cristovão, 2010.

KITINOJA, L. et al. Postharvest technology for developing countries: challenges and opportunities in research, outreach and advocacy. Journal of the Science of Food and Agriculture, v. 91, p. 597603. 2011. PMid:21302312. http://dx.doi.org/10.1002/jsfa.4295

KROKIDA, M. K.; MARINOS-KOURIS, D. Rehydration kinetics of dehydrated products. Journal of Food Engineering, v. 57, p. 1-7, 2003. http://dx.doi.org/10.1016/S0260-8774(02)00214-5

KROKIDA, M. K. et al. Drying kinetics of some vegetables. Journal of Food Engineering, v. 59, p. 391-403, 2003. http://dx.doi. org/10.1016/S0260-8774(02)00498-3

LEWICK, P. P. Some remarks on rehydration of dried foods. Journal of Food Engineering, v. 36, p. 81-87, 1998. http://dx.doi.org/10.1016/ S0260-8774(98)00022-3

MARABI, A. et al. Normalized Weibull distribution for modeling rehydration of food particulates. European Food Research
Technology, v. 217, p. 311-318, 2003. http://dx.doi.org/10.1007/ s00217-003-0719-y

MARQUES, L. G., PRADO, M. M.; FREIRE, J. T. Rehydration characteristics of freeze-dried tropical fruits. LWT-Food Science and Technology, v. 42, p. 1232-1237, 2009. http://dx.doi. org/10.1016/j.lwt.2009.02.012

McMINN, W. A. M.; MAGEE, T. R. A. Physical characteristics of dehydrated potates - part II. Journal of Food Engineering, v. 33, p. 49-55, 1997. http://dx.doi.org/10.1016/S0260-8774(97)00040-X

MILES, T. Agribusiness subsector assessments. In: GIOVANNUCCI, D. (Ed.). A guide to developing agricultural markets and agroenterprises. World Bank: Washington, 2002. Disponível em: <http://go.worldbank.org/J01X2X95U1> Acesso em: 10 nov. 2010.

MOREIRA, R. et al. Water absorption, texture, and color kinetics of air-dried chestnuts during rehydration. Journal of Food Engineering, v. 86, p. 584-594, 2008. http://dx.doi.org/10.1016/j. jfoodeng.2007.11.012

ROESLER, R. et al. Antioxidant activity of Annona crassiflora: characterization of major components by electrospray ionization mass spectrometry. Food Chemistry, v. 104, p. 1048-1054, 2007. http://dx.doi.org/10.1016/j.foodchem.2007.01.017 